\title{
Association of oral Epstein-Barr virus with periodontal health in Japanese adults
}

\author{
CHENG-YIH SU ${ }^{1}$, HIDEO SHIGEISHI ${ }^{2}$, HIROSHI MURODUMI ${ }^{3}$, \\ MASARU SUGIYAMA ${ }^{2}$, KOUJI OHTA ${ }^{2}$ and TOSHINOBU TAKEMOTO ${ }^{1}$ \\ Departments of ${ }^{1}$ Oral Health Management and ${ }^{2}$ Public Oral Health, Program of Oral Health Sciences; \\ ${ }^{3}$ Department of Oral and Maxillofacial Surgery, Program of Dentistry, Graduate School of \\ Biomedical and Health Sciences, Hiroshima University, Hiroshima 734-8553, Japan
}

Received April 16, 2020; Accepted July 15, 2020

DOI: $10.3892 /$ etm.2021.10199

\begin{abstract}
Previous studies have demonstrated that oral Epstein-Barr virus (EBV) is associated with periodontitis. However, the relationship between periodontitis and oral EBV has not been fully elucidated by reducing the effects of confounding factors. The aim of the present study was to clarify the association between oral Epstein-Barr virus (EBV) and oral health status among middle-aged and older Japanese individuals. A total of 124 patients (46 males and 78 females; mean age, 69.2 years; age range, 35-90 years) who visited Hiroshima University Hospital between October 2018 and December 2019 were recruited into the present study. EBV DNA positivity was determined in 124 oral rinse samples using quantitative PCR. Periodontal disease-related bacteria were also detected by PCR analysis. EBV DNA was determined as positive in 16 of the 124 enrolled patients $(12.9 \%)$. No significant difference was identified between EBV DNA and clinical factors (sex, age, remaining teeth, denture use, smoking or medical history). Of the 38 patients with periodontal pockets $\geq 6 \mathrm{~mm}, 10$ were EBV DNA positive (26.3\%). There was a significant association between EBV DNA positivity and probing depth $(\mathrm{P}=0.01)$. Additionally, a significant association was identified between bleeding on probing (BOP) and EBV DNA positivity $(\mathrm{P}=0.03)$. To investigate the relationship between EBV and periodontal health status, propensity score-matching was determined between
\end{abstract}

Correspondence to: Dr Hideo Shigeishi, Department of Public Oral Health, Program of Oral Health Sciences, Graduate School of Biomedical and Health Sciences, Hiroshima University, 1-2-3 Kasumi, Minami-ku, Hiroshima 734-8553, Japan

E-mail: shige@hiroshima-u.ac.jp

Abbreviations: EBV, Epstein-Barr virus; $P$. gingivalis, Porphyromonas gingivalis; T. forsythia, Tannerella forsythia; T. denticola, Treponema denticola; $\mathrm{PCR}$, polymerase chain reaction

Key words: Epstein-Barr virus, periodontitis, periodontal bacteria, polymerase chain reaction, middle-aged and older people participants without $\geq 4 \mathrm{~mm}$ periodontal pockets and BOP (participants with good periodontal health) and those with $\geq 4 \mathrm{~mm}$ periodontal pockets, BOP or both (participants with poor periodontal health). A total of 35 matched pairs were identified among the patients. Patients with poor periodontal health exhibited a higher EBV DNA positivity rate (25.7\%) than those with good periodontal health $(0.0 \%)$. Additionally, there was a significant association between EBV DNA positivity and periodontal health status $(\mathrm{P}=0.001)$. T. denticola-positive participants exhibited a higher EBV DNA positivity rate than negative participants (17.6 vs. 9.6\%). However, there was no significant difference. The results indicated that oral EBV may be markedly associated with periodontitis in middle-aged and older Japanese individuals.

\section{Introduction}

Epstein-Barr virus (EBV), also known as human herpesvirus 4 , is a member of the herpesviridae family. EBV consists of double-stranded DNA (approximately $172 \mathrm{kbp}$ in length) surrounded by a nucleocapsid and an envelope (1). EBV can be transmitted through saliva, and most of the adult population may be infected by EBV by the age of 30 years $(2,3)$. Therefore, it is thought that initial EBV infection usually occurs in adolescents. EBV has been recognized as a cause of cancers, such as Burkitt's lymphoma, Hodgkin's lymphoma, stomach cancer, salivary gland carcinoma and nasopharyngeal carcinoma (4-7).

The oral cavity is an initial site for persistent infection of EBV. The specific histological structure of the tonsillar region may induce sensitivity to EBV infection because lymphoid tissue is abundant in tonsillar tissue. EBV can infect B lymphocytes through saliva and can also infect epithelial cells (8). EBV may also infect both epithelial cells and blood cells in inflammatory periodontal pockets. Epithelial cells play a vital role in the amplification of EBV prior to shedding in saliva $(8,9)$. Thus, the oral cavity may be involved in virus transmission to other sites such as the nasopharynx and gastrointestinal tract.

With regard to the association between oral health status and EBV infection, several previous studies have demonstrated that EBV is strongly associated with periodontitis (10-13). 
The results indicate that inflammatory periodontal pockets may serve as a reservoir of viral organisms in the oral cavity and provide an opportunity for EBV to infect epithelial cells. However, it remains unknown whether EBV is associated with poor oral health (i.e., dental plaque accumulation, an increased oral bacterial count, and a small number of remaining teeth) among middle-aged and older Japanese people. Smoking and diabetes are strongly related to oral EBV prevalence $(14,15)$. However, the relationship between periodontitis and EBV has not been fully elucidated by reducing the effects of confounding factors (i.e., smoking and a medical history of diseases such as diabetes). Therefore, the objective of this study was to clarify the association between oral EBV prevalence and periodontal health status by considering the effects of confounding clinical variables in this population group.

\section{Materials and methods}

Patients and methods. A total of 150 patients who visited the Department of Oral Health of Hiroshima University Hospital between October 2018 and December 2019 were enrolled in the present study. We excluded subjects with oral cancer or potentially malignant oral disorders (i.e., leukoplakia or lichen planus) $(n=1)$, cancer patients receiving surgical treatment, chemotherapy or radiotherapy $(n=20)$, those with auto-immune diseases receiving steroid therapy $(n=3)$ and those with severe immunodeficiency $(n=2)$. We included smokers and patients with a medical history of hypertension, diabetes, hyperlipidemia, stroke, heart disease, or bone and joint disease. Finally, we analyzed 124 patients (46 males and 78 females; mean age, 69.2 years; age range, 35-90 years) in this study. The design of this cross-sectional study was approved by the Ethical Committee of Hiroshima University. All participants signed an informed consent agreement.

Oral rinse sample processing and DNA extraction. Oral rinse samples were obtained by asking the subjects to rinse their mouths with $10 \mathrm{ml}$ of saline for $15 \mathrm{sec}$. Samples were collected in sterile $15-\mathrm{ml}$ tubes, and immediately centrifuged. The supernatant was decanted and the pellets were stored at $-80^{\circ} \mathrm{C}$. DNA was extracted using a PureLink ${ }^{\mathrm{TM}}$ Microbiome DNA Purification kit (Thermo Fisher Scientific, Inc.), according to the manufacturer's protocol.

Oral examination. Bacterial numbers on the tongue surface were measured using a bacterial counter (Panasonic Healthcare Co., Ltd.) (16). Samples were obtained from the tongue surface using a cotton swab, according to the manufacturer's protocol, and then the oral rinse sample was collected. Probing depth and bleeding on probing (BOP) were then assessed at six sites (mesiobuccal, mesiolingual, buccal, lingual, distobuccal, and distolingual) on all remaining teeth. BOP was recorded as positive when blood flow from the gingival sulcus was observed. BOP was recorded as negative when no bleeding or a small bleeding point was observed. Next, plaque control record scores were recorded according to O'Leary's method using a plaque disclosing agent to examine dental plaque accumulation (17). The number of remaining teeth and denture use were also recorded.

Quantitation of human cell numbers. In accordance with the methods of a previous study (18), the human endogenous
Table I. Association between oral EBV DNA and clinical parameters.

\begin{tabular}{|c|c|c|c|}
\hline \multirow[b]{2}{*}{ Clinical factor (n) } & \multicolumn{2}{|c|}{ EBV DNA } & \multirow[b]{2}{*}{ P-value } \\
\hline & Negative & Positive & \\
\hline Age, years ${ }^{\mathrm{a}}$ & $69.1 \pm 11.6$ & $69.4 \pm 12.6$ & 0.74 \\
\hline Sex, n $(\%)$ & & & 0.59 \\
\hline Male (46) & $39(84.8)$ & $7(15.2)$ & \\
\hline Female (78) & $69(88.5)$ & $9(11.5)$ & \\
\hline Remaining teeth $^{\mathrm{a}}$ & $23.0 \pm 6.7$ & $23.9 \pm 4.5$ & 0.77 \\
\hline Denture user, n (\%) & & & $>0.99$ \\
\hline Non-user (90) & $78(86.7)$ & $12(13.3)$ & \\
\hline User (34) & $30(88.2)$ & $4(11.8)$ & \\
\hline Smoking, n (\%) & & & 0.43 \\
\hline No (120) & $105(87.5)$ & $15(12.5)$ & \\
\hline Yes (4) & $3(75.0)$ & $1(25.0)$ & \\
\hline Hypertension, n (\%) & & & 0.20 \\
\hline No (96) & $86(89.6)$ & $10(10.4)$ & \\
\hline Yes (28) & $22(78.6)$ & $6(21.4)$ & \\
\hline \multicolumn{4}{|l|}{ Diabetes, n (\%) } \\
\hline No (111) & $96(86.5)$ & $15(13.5)$ & $>0.99$ \\
\hline Yes (13) & $12(92.3)$ & $1(7.7)$ & \\
\hline \multicolumn{4}{|l|}{ Hyperlipidemia, n (\%) } \\
\hline No (100) & $88(88.0)$ & $12(12.0)$ & 0.51 \\
\hline Yes (24) & $20(83.3)$ & $4(16.7)$ & \\
\hline \multicolumn{4}{|l|}{ Stroke, n (\%) } \\
\hline No (118) & $104(88.1)$ & $14(11.9)$ & 0.17 \\
\hline Yes (6) & $4(66.7)$ & $2(33.3)$ & \\
\hline \multicolumn{4}{|l|}{ Heart disease, n (\%) } \\
\hline No (117) & $102(87.2)$ & $15(12.8)$ & 0.68 \\
\hline Yes (7) & $6(85.7)$ & $1(14.3)$ & \\
\hline \multicolumn{4}{|c|}{$\begin{array}{l}\text { Bone and joint disease, } \\
\mathrm{n}(\%)\end{array}$} \\
\hline No (117) & $102(87.2)$ & $15(12.8)$ & 0.68 \\
\hline Yes (7) & $6(85.7)$ & $1(14.3)$ & \\
\hline
\end{tabular}

${ }^{\text {aD }}$ ata are presented as the mean \pm SD. EBV, Epstein-Barr virus.

retrovirus group 3 member 1 (ERV3-1) gene was employed to quantitate human cells using quantitative polymerase chain reaction (PCR). DNA levels were quantitated using a CFX Connect real-time PCR detection system (Bio-Rad Laboratories, Inc.). The reaction mixture contained SYBR Green PCR Master Mix (Toyobo Life Science), $1.0 \mu 1$ DNA and $10 \mu \mathrm{mol}$ of each pair of oligonucleotide primers. Amplifications were performed with initial melting at $95^{\circ} \mathrm{C}$ for $5 \mathrm{~min}$, followed by 40 cycles of $95^{\circ} \mathrm{C}$ for $30 \mathrm{sec}, 57^{\circ} \mathrm{C}$ for $30 \mathrm{sec}$ and $72^{\circ} \mathrm{C}$ for $1 \mathrm{~min}$.

EBV DNA detection. Real-time PCR analysis was performed to determine EBV DNA copy number in the samples using a CFX Connect real-time PCR detection system. A 180-bp 
Table II. Association between oral EBV DNA and oral health.

\begin{tabular}{|c|c|c|c|}
\hline \multirow[b]{2}{*}{ Factor (n) } & \multicolumn{2}{|c|}{ EBV DNA } & \multirow[b]{2}{*}{ P-value } \\
\hline & Negative & Positive & \\
\hline Plaque control record scores $(\%)^{\mathrm{a}}$ & $36.2 \pm 18.4$ & $40.3 \pm 19.4$ & 0.34 \\
\hline Probing depth [mm, n (\%)] & & & 0.01 \\
\hline$<4(52)$ & $49(96.4)$ & $3(3.6)$ & \\
\hline$\geq 4$ and $<6(34)$ & $31(91.2)$ & $3(8.8)$ & \\
\hline$\geq 6(38)$ & $28(73.7)$ & $10(26.3)$ & \\
\hline BOP, n (\%) & & & 0.03 \\
\hline No $(71)$ & $66(93.0)$ & $5(7.0)$ & \\
\hline Yes $(53)$ & $42(79.2)$ & $11(20.8)$ & \\
\hline$\geq 6 \mathrm{~mm}$ periodontal pocket with $\mathrm{BOP}, \mathrm{n}(\%)$ & & & 0.02 \\
\hline No (99) & $90(90.9)$ & $9(9.1)$ & \\
\hline Yes $(25)$ & $18(72.0)$ & $7(28.0)$ & \\
\hline Oral bacteria number ${ }^{a}\left(1.0 \times 10^{6} \mathrm{CFU} / \mathrm{ml}\right)$ & $8.1 \pm 6.1$ & $7.8 \pm 9.0$ & 0.30 \\
\hline
\end{tabular}

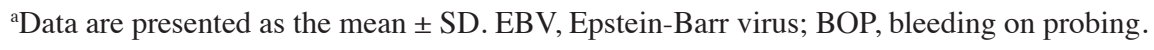

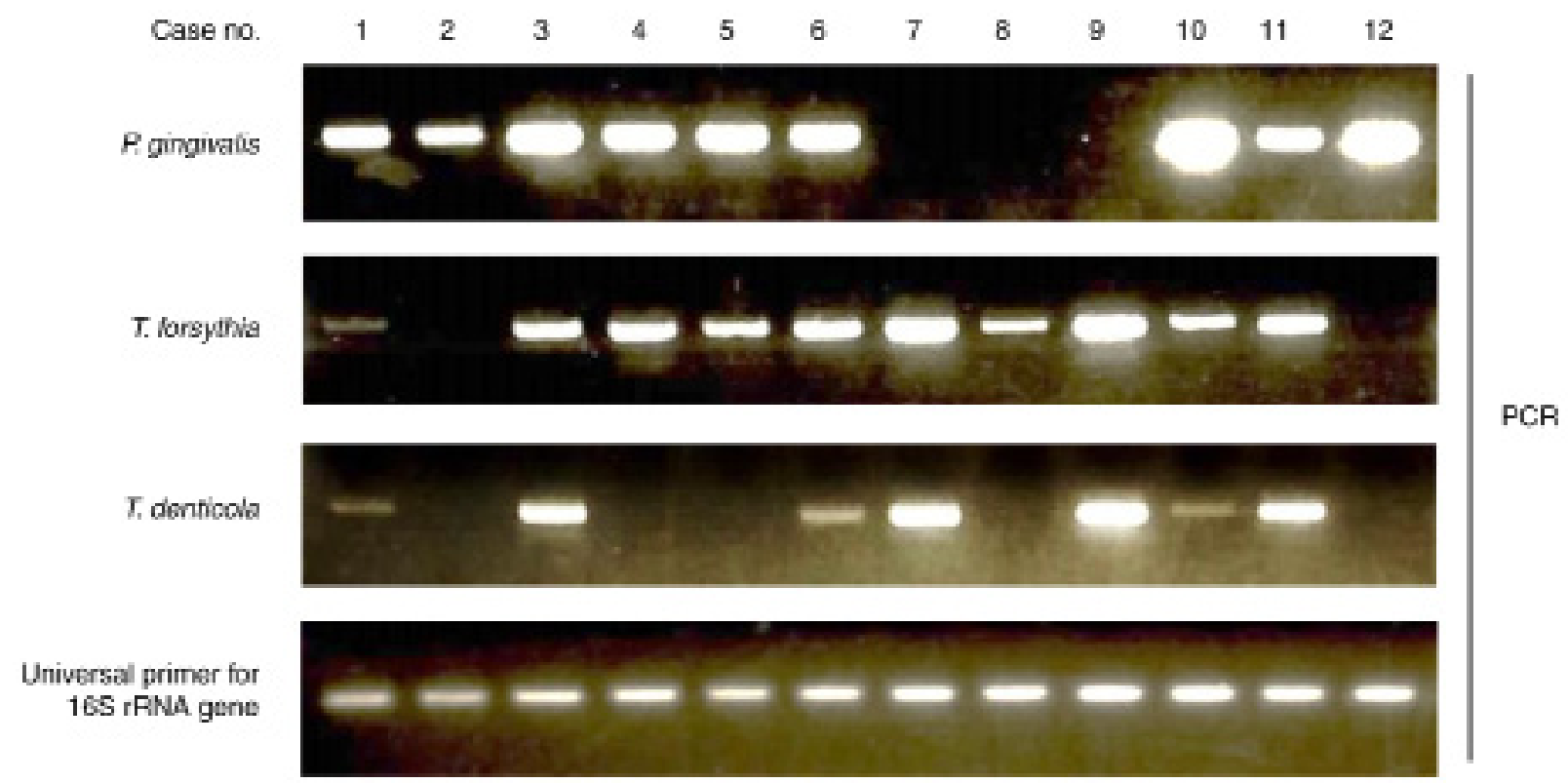

Figure 1.PCR detection of periodontal disease-related bacteria. PCR was performed to detect $P$. gingivalis, T. forsythia, and T. denticola DNA. The PCR product was electrophoresed on $2 \%$ agarose gels with ethidium bromide staining and visualized using an ultraviolet transilluminator. P. gingivalis, Porphyromonas gingivalis; T. forsythia, Tannerella forsythia; T. denticola, Treponema denticola; rRNA, ribosomal RNA.

fragment within the EBV genome was prepared, which was cloned into a pUC57 vector (GenScript Biotech Corporation,). We generated a standard curve using real-time PCR analysis, which indicated the CT value vs. the copy number of EBV. Amplifications were performed with a cycle of $95^{\circ} \mathrm{C}$ for $5 \mathrm{~min}$, followed by 40 cycles of $95^{\circ} \mathrm{C}$ for $1 \mathrm{~min}, 58^{\circ} \mathrm{C}$ for $1 \mathrm{~min}$ and $72^{\circ} \mathrm{C}$ for $1 \mathrm{~min}$. Next, real-time PCR was performed to detect EBV DNA. DNA samples containing 1,000-10,000 human cells per 1.0 $\mu \mathrm{l}$ DNA were used for PCR analysis. The primer sequences for $E B V$ were 5'-CCTGGTCATCCT TTGCCA-3' (sense) and 5'-TGCTTCGTTATAGCCGTA
GT-3' (antisense) (19). Copy numbers above the detection limit in a standard curve for EBV DNA were assessed as EBV positive. EBV DNA copy number was presented as the mean \pm standard deviation of three independent experiments. ERV3-1 gene was used as an internal control for real-time PCR analysis.

Periodontal disease-related bacteria detection by PCR. According to our previous study, periodontal disease-related bacteria were detected by PCR with specific DNA primer sets (20). After the PCR reaction, the PCR product was 
electrophoresed on $2 \%$ agarose gels with ethidium bromide staining.

Statistical analysis. The $\chi^{2}$ test or Fisher's exact test were used to evaluate significant differences between positive rates of EBV DNA and clinical factors. The Mann-Whitney U test was used to compare differences in clinical parameters between two groups. The Kruskal-Wallis test was used to compare differences in clinical parameters among three groups. If the Kruskal-Wallis test was significant, the Nemenyi test was performed. A propensity score-matched analysis was employed to decrease the effects of confounders. Propensity scores were calculated by logistic regression analysis of 11 clinical factors (age, sex, remaining teeth, denture use, smoking, hypertension, diabetes, hyperlipidemia, stroke, heart disease, and bone and joint disease). The results of the Hosmer-Lemeshow test was not statistically significant $(\mathrm{P}=0.44)$, suggesting good fitness of the model. A caliper of 0.25 standard deviation of the propensity score was used for analysis. Statistical analysis was performed using SPSS version 24.0 (IBM Corp.). $\mathrm{P}<0.05$ was considered to indicate a statistically significant difference.

\section{Results}

Association between EBV DNA positivity and clinical factors. EBV DNA positivity was examined in a total of 124 oral rinse samples using real-time PCR. EBV DNA was determined as positive in 16 of 124 participants (12.9\%). The number of EBV DNA copies was evaluated as copy number/100 human cells. The average number of EBV viral copies was $5.3 \pm 4.8$ copies $/ 100$ cells (range, $0.8-13.8$ copies $/ 100$ cells). Table I summarizes the relationship between EBV DNA and clinical parameters. No significant difference was found between EBV DNA and clinical factors (i.e., sex, age, remaining teeth, denture use or medical history). Smokers exhibited a higher EBV DNA positivity rate $(25.0 \%)$ than non-smokers $(12.5 \%)$, but a significant association was not found.

Association between EBV DNA positivity and dental plaque accumulation and periodontal condition. Next, the relationship between EBV DNA positivity and dental plaque accumulation and periodontal health condition was examined. Associations between EBV DNA positivity and dental plaque accumulation and periodontal health condition are summarized in Table II. There was no significant difference between EBV DNA positivity and the plaque control record score. Ten of the 38 participants with periodontal pockets $\geq 6 \mathrm{~mm}$ were EBV DNA positive (26.3\%). There was a significant association between EBV DNA positivity and probing depth. Subjects with BOP exhibited a higher EBV DNA positivity rate $(20.8 \%)$ than those without BOP (7.0\%). A significant association was found between BOP and EBV DNA positivity. Additionally, subjects with $\geq 6 \mathrm{~mm}$ periodontal pockets with BOP recorded a higher EBV DNA positivity rate $(28.0 \%)$ than those without $\geq 6 \mathrm{~mm}$ periodontal pockets with BOP $(9.1 \%)$. There was a significant association between $\geq 6 \mathrm{~mm}$ periodontal pockets with BOP and EBV DNA positivity. However, no significant difference was found between EBV DNA positivity and bacterial numbers.
Table III. Association between oral EBV DNA and periodontal disease-related bacteria.

\begin{tabular}{lccc}
\hline & \multicolumn{2}{c}{ EBV DNA } & \\
\cline { 2 - 3 } $\begin{array}{l}\text { Periodontal } \\
\text { bacteria (n) }\end{array}$ & $\begin{array}{c}\text { Negative, } \\
\mathrm{n}(\%)\end{array}$ & $\begin{array}{c}\text { Positive, } \\
\mathrm{n}(\%)\end{array}$ & P-value \\
\hline $\begin{array}{l}P \text {. gingivalis } \\
\text { Negative (56) }\end{array}$ & $48(85.7)$ & $8(14.3)$ & 0.79 \\
Positive (68) & $60(88.2)$ & $8(11.8)$ & \\
$T$. forsythia & & & 0.56 \\
Negative (32) & $27(84.4)$ & $5(15.6)$ & \\
Positive (92) & $81(88.0)$ & $11(12.0)$ & \\
$T$. denticola & & & 0.28 \\
Negative (73) & $66(90.4)$ & $7(9.6)$ & \\
Positive (51) & $42(82.4)$ & $9(17.6)$ & \\
\hline
\end{tabular}

EBV, Epstein-Barr virus.

Association between EBV DNA positivity and periodontal disease-related bacteria. In this study, we investigated the so-called red complex bacteria which are the most vital pathogens in chronic periodontal disease (21). PCR was performed to detect $P$. gingivalis, $T$. forsythia, and T. denticola DNA (Fig. 1). Associations between EBV DNA positivity and red complex bacteria are summarized in Table III. T. denticola positive participants exhibited a higher EBV DNA positivity rate than negative participants (17.6\% vs. 9.6\%). However, there was no significant association between EBV DNA positivity and periodontal disease-related bacteria.

Association between EBV DNA copy number and periodontal condition. To examine the relationship between virus DNA amplification and periodontal tissue condition (i.e., periodontal pocket depth or BOP), we investigated the EBV DNA copy number in $16 \mathrm{EBV}$ positive cases. Associations between EBV DNA copy number/100 human cells and the periodontal condition of EBV positive cases are presented in Fig. 2. There was no significant association between EBV DNA copy number and periodontal pocket depth or BOP. Additionally, there was no significant increase in the EBV DNA copy number in people with $\geq 6 \mathrm{~mm}$ periodontal pockets and BOP as compared to those without $\geq 6 \mathrm{~mm}$ periodontal pockets and BOP.

Association between EBV DNA positivity and periodontal health status in propensity score-matched cases. Propensity score-matching was performed between participants without $\geq 4 \mathrm{~mm}$ periodontal pockets and BOP (participants with good periodontal health) and those with $\geq 4 \mathrm{~mm}$ periodontal pockets, BOP or both (participants with poor periodontal health) using propensity scores generated from 11 clinical factors (age, sex, remaining teeth, denture use, smoking, hypertension, diabetes, hyperlipidemia, stroke, heart disease, and bone and joint disease). A total of 70 propensity score-matched cases (35 participants in matched pairs) were evaluated by univariate analysis. We confirmed that none of the 11 clinical variables 


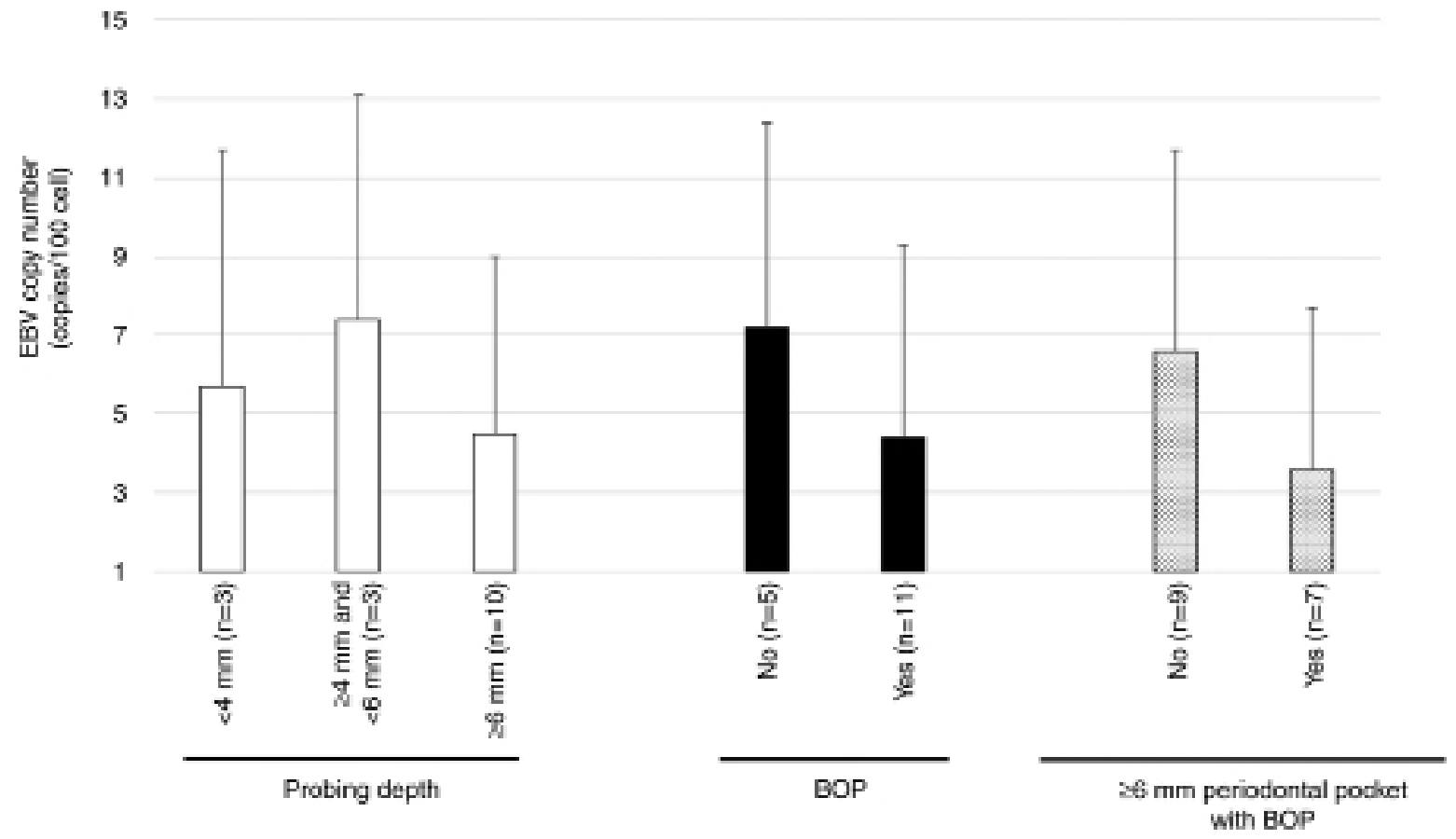

Figure 2. Association between EBV DNA copy number and periodontal condition in EBV positive cases. There was no statistically significant difference between each group. EBV, Epstein-Barr virus.

were significantly associated with EBV DNA positivity (Table IV). Next, we investigated the association between EBV DNA positivity and periodontal health status. Participants with poor periodontal health exhibited a higher EBV DNA positivity rate $(25.7 \%)$ than those with good periodontal health $(0.0 \%)$. There was a significant association between EBV DNA positivity and periodontal health status $(\mathrm{P}=0.001)$ (Table V).

\section{Discussion}

Periodontitis is a chronic inflammatory disease, and periodontitis-related bacteria play a vital role in the initiation and progression of periodontitis. Herpes viruses as well as periodontitis-related bacteria have been reported to be involved in aggressive periodontal disease (22). The herpes virus may be involved in the change of cell structure in periodontal tissues and has cytopathic effects on inflammatory cells such as leukocytes, lymphocytes and macrophages (22). High levels of cytomegalovirus and $P$. gingivalis were detected in school children with juvenile periodontitis in Jamaica (23). HSV-1 and EBV were detected more frequently in Brazilian people with chronic periodontitis or aggressive periodontal disease than in people without periodontitis (11). EBV DNA was more frequently detected in individual periodontal pockets with $\geq 5 \mathrm{~mm}$ probing depth than in healthy sites with $\leq 3 \mathrm{~mm}$ probing depth in patients with periodontal disease in the US population (12). A meta-analysis based on case control studies revealed that there was a significant relationship between EBV or human cytomegalovirus infection and chronic periodontitis $(13,24)$. In this study, we found there was a significant association between oral EBV and periodontal pocket depth and BOP. BOP is considered to be a significant indicator of periodontal tissue inflammation (25).
Additionally, subjects with $\geq 6 \mathrm{~mm}$ periodontal pockets with BOP exhibited a higher EBV DNA positivity rate than those without $\geq 6 \mathrm{~mm}$ periodontal pockets with BOP. Furthermore, a propensity score-matched analysis revealed that people with poor periodontal health exhibited a significantly higher EBV DNA positivity rate than those with good periodontal health, suggesting that there was a close association between periodontitis and EBV prevalence.

There was no significant association between EBV DNA positivity and periodontal disease-related bacteria such as $P$. gingivalis, T. forsythia and T. denticola. It remains unclear whether periodontal disease-related bacteria are associated with EBV prevalence. In contrast, human cytomegalovirus promotes the virulence of periodontal disease-related bacteria such as Actinobacillus actinomycetemcomitans (26). EBV prevalence may be associated with enhanced pathogenicity of periodontal disease-related bacteria. Additionally, there was no significant relationship between EBV DNA copy number and periodontal condition. In contrast, the EBV DNA copy number was significantly higher in subjects with periodontitis than in those with gingivitis and normal subjects, indicating that EBV gene amplification may be related to periodontal inflammation (27). Further study is required to clarify the relationship between EBV DNA amplification and the severity of periodontal inflammation.

The results of this study suggest that local periodontal inflammation and an inhibited local immune system may provide the opportunity for EBV to infect epithelial cells in the oral cavity (i.e., recent EBV infection). In addition, persistent EBV-infected blood cells may have been reactivated in accordance with periodontal inflammation (i.e., reactivation of EBV-infected lymphocytes). However, it remains unknown which of these factors is a major cause of the prevalence of oral EBV in this study. 
Table IV. Characteristics of participants with good periodontal health and those with poor periodontal health comprising 70 propensity score matched participants.

\begin{tabular}{|c|c|c|c|}
\hline Clinical factor (n) & $\begin{array}{l}\text { Participants with good } \\
\text { periodontal health }(n=35)\end{array}$ & $\begin{array}{l}\text { Participants with poor } \\
\text { periodontal health }(\mathrm{n}=35)\end{array}$ & P-value \\
\hline Age, years ${ }^{\mathrm{a}}$ & $68.7 \pm 10.3$ & $68.4 \pm 9.4$ & 0.77 \\
\hline Sex, n (\%) & & & $>0.99$ \\
\hline Male (24) & $12(50.0)$ & $12(50.0)$ & \\
\hline Female (46) & $23(50.0)$ & $23(50.0)$ & \\
\hline Remaining teeth ${ }^{\mathrm{a}}$ & $22.5 \pm 7.3$ & $22.2 \pm 7.0$ & 0.31 \\
\hline Denture user, n (\%) & & & $>0.99$ \\
\hline Non-user (50) & $25(50.0)$ & $25(50.0)$ & \\
\hline User (20) & $10(50.0)$ & $10(50.0)$ & \\
\hline Smoking, n (\%) & & & $>0.99$ \\
\hline No (67) & $33(49.3)$ & $34(50.7)$ & \\
\hline Yes (3) & $2(66.7)$ & $1(33.3)$ & \\
\hline Hypertension, n (\%) & & & $>0.99$ \\
\hline No (57) & $28(49.1)$ & $29(50.9)$ & \\
\hline Yes (13) & $7(53.8)$ & $6(46.2)$ & \\
\hline Diabetes, n (\%) & & & $>0.99$ \\
\hline No $(62)$ & $31(50.0)$ & $31(50.0)$ & \\
\hline Yes (8) & $4(50.0)$ & $4(50.0)$ & \\
\hline Hyperlipidemia, n (\%) & & & $>0.99$ \\
\hline No (55) & $28(50.9)$ & $27(49.1)$ & \\
\hline Yes (15) & $7(46.7)$ & $8(53.3)$ & \\
\hline Stroke, $\mathrm{n}(\%)$ & & & $>0.99$ \\
\hline No (66) & $33(50.0)$ & $33(50.0)$ & \\
\hline Yes (4) & $2(50.0)$ & $2(50.0)$ & \\
\hline Heart disease, $\mathrm{n}(\%)$ & & & $>0.99$ \\
\hline No (68) & $34(50.0)$ & $34(50.0)$ & \\
\hline Yes (2) & $1(50.0)$ & $1(50.0)$ & \\
\hline Bone and joint disease, $\mathrm{n}(\%)$ & & & $>0.99$ \\
\hline No $(67)$ & $34(50.7)$ & $33(49.3)$ & \\
\hline Yes (3) & $1(33.3)$ & $2(66.7)$ & \\
\hline
\end{tabular}

${ }^{\mathrm{a}}$ Data are presented as the mean $\pm \mathrm{SD}$.

Table V. Association between oral EBV DNA and periodontal health status in 70 propensity score-matched cases.

\begin{tabular}{lccr}
\hline & \multicolumn{2}{c}{ EBV DNA } \\
\cline { 2 - 3 } Periodontal health status & Negative, $\mathrm{n}(\%)$ & Positive, $\mathrm{n}(\%)$ & P-value \\
\hline Participants with good periodontal health $(\mathrm{n}=35)$ & $35(100.0)$ & $0(0.0)$ & 0.001 \\
Participants with poor periodontal health $(\mathrm{n}=35)$ & $26(74.3)$ & $9(25.7)$ & \\
\hline
\end{tabular}

EBV, Epstein-Barr virus.

As for the association between EBV DNA and clinical factors, there was no significant difference between EBV DNA and sex, age, remaining teeth, denture use, or medical history. Diabetic patients were more susceptible to oral EBV than non-diabetic patients (15). Thus, diabetes is thought to be an important risk factor in the prevalence of oral EBV DNA. However, no significant relationship was found between oral EBV prevalence and diabetes in this study. Good diabetes 
control in diabetic patients may have contributed to their lower oral EBV positivity rate.

Research has shown that current smoking increases the oral EBV load in people in China (14). This result indicates that smoking may enhance EBV activity and induce persistent EBV infection. Smoking is thought to be a significant risk factor in the prevalence of oral EBV DNA due to the smoking-inhibited immune response. In this study, no association was found between smoking and EBV positivity, possibly because the number of smokers in this study was small. Further study will be required to clarify the association between smoking and EBV by including many more smokers in the study cohort. Acharya et al reported that there was a significant relationship between betel nut chewing and oral EBV prevalence (28). It is hypothesized that betel nut chewing may have an impact on EBV infection in the oral cavity. Betel nut chewing may inhibit immune responses due to the action of alkaloids such as arecoline (29). Betel nut chewing also results in constant injury to the oral mucosa, providing an opportunity for EBV to infect oral epithelial cells. Smoking and betel nut chewing may contribute to persistent EBV infection and reactivation of EBV in the oral cavity.

Latent EBV genomes express EBV-encoded nuclear antigens $1,2,3 \mathrm{~A}, 3 \mathrm{~B}$, and $3 \mathrm{C}$, latent membrane proteins and small noncoding RNAs (30). These proteins are importantly related to B-cell immortalization and development of B-cell lymphoma (30). BamHI A rightward transcripts (BARTs) and EBV-encoded microRNAs derived from the BARTs are involved in malignant transformation of epithelial cells (31). These results indicate that EBV infection is implicated in the development of epithelial malignant tumors. EBV has been detected not only in normal oral epithelium but also in oral lichen planus and oral squamous cell carcinoma $(28,32,33)$, supporting the idea that EBV plays a vital role in oral cavity cancer development. Furthermore, persistent EBV infection due to smoking may increase the risk of EBV-related epithelial malignant tumors. However, it remains unknown how EBV induces the development of cancer in the oral cavity. The oral cavity mainly acts as a reservoir to provide EBV for other anatomical sites such as the stomach and nasopharynx. Accordingly, it is essential to prevent primary oral EBV infection to prevent secondary EBV infections in the nasopharynx and gastrointestinal tract.

In this study, the plaque control record scores were higher in EBV-positive individuals than in EBV-negative individuals, but there was no significant association between dental plaque accumulation and the EBV positivity rate. EBV was detected in the subgingival dental plaque in deep periodontal pockets (12). Dental plaque accumulation may be related to EBV prevalence in the oral cavity. Thus, regular oral health care (i.e., subgingival plaque removal using a toothbrush and subgingival scaling) is necessary not only to prevent periodontal disease, but also to prevent EBV infection in periodontal tissue.

In conclusion, oral EBV infection is thought to be associated with periodontitis in middle-aged and older Japanese people. However, it remains unknown whether EBV can localize in periodontal tissues. The association between oral EBV and the severity of periodontitis (i.e., the degree of alveolar bone loss) was not elucidated in this study. Accordingly, further study is required to uncover the presence of EBV in inflammatory periodontal tissues and to determine the relationship between EBV and the severity of periodontitis.

\section{Acknowledgements}

Not applicable.

\section{Funding}

The present study was financially supported by university grants from Hiroshima University.

\section{Availability of data and materials}

All data generated or analyzed during this study are included in this published article.

\section{Authors' contributions}

CYS performed experiments and analyzed and interpreted the data. HS designed the study, performed the experiments, analyzed and interpreted the data, and wrote the manuscript. $\mathrm{HM}$ performed the experiments and analyzed the data. KO and TT discussed and analyzed the data and aided in writing the paper. MS designed the current study and discussed data analysis. All authors read and approved the final manuscript.

\section{Ethics approval and consent to participate}

The Ethical Committee of Hiroshima University approved the present study (approval no. E-1115). All participants provided their written informed consent prior to participation.

\section{Patient consent for publication}

Not applicable.

\section{Competing interests}

The authors declare that they have no competing interests.

\section{References}

1. Baer R, Bankier AT, Biggin MD, Deininger PL, Farrell PJ, Gibson TJ, Hatfull G, Hudson GS, Satchwell SC, Séguin C, et al: DNA sequence and expression of the B95-8 Epstein-Barr virus genome. Nature 310: 207-211, 1984.

2. Houldcroft CJ and Kellam P: Host genetics of Epstein-Barr virus infection, latency and disease. Rev Med Virol 25: 71-84, 2015.

3. Cohen JI: Epstein-Barr virus infection. N Engl J Med 343: 481-492, 2000

4. Epstein MA: Reflections on Epstein-Barr virus: Some recently resolved old uncertainties. J Infect 43: 111-115, 2001

5. Hjalgrim H, Askling J, Rostgaard K, Hamilton-Dutoit S, Frisch M, Zhang JS, Madsen M, Rosdahl N, Konradsen HB, Storm HH and Melbye M: Characteristics of Hodgkin's lymphoma after infectious mononucleosis. N Engl J Med 349: 1324-1332, 2003.

6. Cho WC: Nasopharyngeal carcinoma: Molecular biomarker discovery and progress. Mol Cancer 6: 1, 2007.

7. Shibata D, Tokunaga M, Uemura Y, Sato E, Tanaka S and Weiss LM: Association of Epstein-Barr virus with undifferentiated gastric carcinomas with intense lymphoid infiltration. Lymphoepithelioma-like carcinoma. Am J Pathol 139: 469-474, 1991.

8. Jiang R, Scott RS and Hutt-Fletcher LM: Epstein-Barr virus shed in saliva is high in B-cell-tropic glycoprotein gp42. J Virol 80: 7281-7283, 2006

9. Hadinoto V, Shapiro M, Sun CC and Thorley-Lawson DA: The dynamics of EBV shedding implicate a central role for epithelial cells in amplifying viral output. PLoS Pathog 5: e1000496, 2009. 
10. Kamma JJ, Contreras A and Slots J: Herpes viruses and periodontopathic bacteria in early-onset periodontitis. J Clin Periodontol 28: 879-885, 2001.

11. Imbronito AV, Okuda OS, Maria de Freitas N, Moreira Lotufo RF and Nunes FD: Detection of herpesviruses and periodontal pathogens in subgingival plaque of patients with chronic periodontitis, generalized aggressive periodontitis, or gingivitis. J Periodontol 79: 2313-2321, 2008.

12. Dawson DR, Wang C, Danaher RJ, Lin Y, Kryscio RJ, Jacob RJ and Miller CS: Real-time polymerase chain reaction to determine the prevalence and copy number of Epstein-Barr virus and cytomegalovirus DNA in subgingival plaque at individual healthy and periodontal disease sites. J Periodontol 80: 1133-1140, 2009.

13. Zhu C, Li F, Wong MC, Feng XP, Lu HX and Xu W: Association between Herpesviruses and chronic periodontitis: A meta-analysis based on case-control studies. PLoS One 10: e0144319, 2015

14. He YQ, Liao XY, Xue WQ, Xu YF, Xu FH, Li FF, Li XZ, Zhang JB, Wang TM, Wang F, et al: Association between environmental factors and oral Epstein-Barr virus DNA loads: A multicenter cross-sectional study in China. J Infect Dis 219: 400-409, 2019

15. Dworzański J, Drop B, Kliszczewska E, Strycharz-Dudziak M and Polz-Dacewicz M: Prevalence of Epstein-Barr virus, human papillomavirus, cytomegalovirus and herpes simplex virus type 1 in patients with diabetes mellitus type 2 in south-eastern Poland. PLoS One 14: e0222607, 2019.

16. Hamada R, Suehiro J, Nakano M, Kikutani T and Konishi K: Development of rapid oral bacteria detection apparatus based on dielectrophoretic impedance measurement method. IET Nanobiotechnol 5: 25-31, 2011.

17. O'Leary TJ, Drake RB and Naylor JE: The plaque control record. J Periodontol 43: 38, 1972.

18. Shigeishi H, Sugiyama M, Ohta K, Rahman MZ and Takechi M: Higher prevalence and gene amplification of HPV16 in oropharynx as compared to oral cavity. J Appl Oral Sci 24: 397-403, 2016.

19. Kato A, Imai K, Sato H and Ogata Y: Prevalence of Epstein-Barr virus DNA and Porphyromonas gingivalis in Japanese peri-implantitis patients. BMC Oral Health 17: 148, 2017.

20. Su CY, Shigeishi H, Nishimura R, Ohta K and Sugiyama M: Detection of oral bacteria on the tongue dorsum using PCR amplification of $16 \mathrm{~S}$ ribosomal RNA and its association with systemic disease in middle-aged and elderly patients. Biomed Rep 10: 70-76, 2019

21. Socransky SS, Haffajee AD, Cugini MA, Smith $\mathrm{C}$ and Kent RL Jr: Microbial complexes in subgingival plaque. J Clin Periodontol 25: 134-144, 1998.
22. Slots $\mathbf{J}$ and Contreras A: Herpesviruses: A unifying causative factor in periodontitis? Oral Microbiol Immunol 15: 277-280, 2000.

23. Michalowicz BS, Ronderos M, Camara-Silva R, Contreras A and Slots J: Human herpesviruses and Porphyromonas gingivalis are associated with juvenile periodontitis. J Periodontol 71: 981-988, 2000.

24. Gao Z, Lv J and Wang M: Epstein-Barr virus is associated with periodontal diseases: A meta-analysis based on 21 case-control studies. Medicine (Baltimore) 96: e5980, 2017.

25. de Souza PH, de Toledo BE, Rapp GE, Zuza EP, Neto CB and Mendes AJ: Reliability of bleeding and non-bleeding on probing to gingival histological features. J Int Acad Periodontol 5: 71-76, 2003.

26. Teughels W, Sliepen I, Quirynen M, Haake SK, Van Eldere J, Fives-Taylor P and Van Ranst M: Human cytomegalovirus enhances A. actinomycetemcomitans adherence to cells. J Dent Res 86: 175-180, 2007.

27. Srivastava AK, Shukla S, Srivastava P, Dhole TN, Nayak MT, Nayak A and Mathur A: Real time detection and quantification of Epstein Barr virus in different grades of oral gingivitis and periodontitis patients. J Exp Ther Oncol 13: 9-14, 2019.

28. Acharya S, Ekalaksananan T, Vatanasapt P, Loyha K, Phusingha P, Promthet S, Kongyingyoes B and Pientong C: Association of Epstein-Barr virus infection with oral squamous cell carcinoma in a case-control study. J Oral Pathol Med 44: 252-257, 2015.

29. Singh PN, Natto Z, Yel D, Job J and Knutsen S: Betel quid use in relation to infectious disease outcomes in Cambodia. Int J Infect Dis 16: e262-e267, 2012.

30. Saha A and Robertson ES: Epstein-Barr virus-associated B-cell lymphomas: Pathogenesis and clinical outcomes. Clin Cancer Res 7: 3056-3063, 2011

31. Tsao SW, Tsang CM, To KF and Lo KW: The role of Epstein-Barr virus in epithelial malignancies. J Pathol 235: 323-333, 2015.

32. Mao EJ and Smith CJ: Detection of Epstein-Barr virus (EBV) DNA by the polymerase chain reaction (PCR) in oral smears from healthy individuals and patients with squamous cell carcinoma. J Oral Pathol Med 22: 12-17, 1993.

33. Sand LP, Jalouli J, Larsson PA and Hirsch JM: Prevalence of Epstein-Barr virus in oral squamous cell carcinoma, oral lichen planus, and normal oral mucosa. Oral Surg Oral Med Oral Pathol Oral Radiol Endod 93: 586-592, 2002. 